Article

\title{
Formaldehyde in Hospitals Induces Oxidative Stress: The Role of GSTT1 and GSTM1 Polymorphisms
}

\author{
Federica Ghelli ${ }^{1, \dagger}{ }^{\dagger}$, Valeria Bellisario ${ }^{1, \dagger}$, Giulia Squillacioti ${ }^{1} @$, Marco Panizzolo ${ }^{1}$, Alfredo Santovito ${ }^{2, \ddagger}$ and \\ Roberto Bono $1, *, \ddagger$ (iD) \\ 1 Department of Public Health and Pediatrics, University of Turin, 10126 Turin, Italy; \\ federica.ghelli@unito.it (F.G.); valeria.bellisario@unito.it (V.B.); giulia.squillacioti@unito.it (G.S.); \\ marco.panizzolo@unito.it (M.P.) \\ 2 Department of Life Sciences and Systems Biology, University of Turin, 10123 Turin, Italy; \\ alfredo.santovito@unito.it \\ * Correspondence: roberto.bono@unito.it; Tel.: +39-011-670-5818 \\ + These authors contributed equally to this work as first author. \\ $\ddagger \quad$ These authors contributed equally to this work as last author.
}

Citation: Ghelli, F.; Bellisario, V.; Squillacioti, G.; Panizzolo, M.; Santovito, A.; Bono, R. Formaldehyde in Hospitals Induces Oxidative Stress: The Role of GSTT1 and GSTM1 Polymorphisms. Toxics 2021, 9, 178. https://doi.org/10.3390/toxics9080178

Academic Editors: Mirta Milić and Jeroen Vanoirbeek

Received: 21 June 2021

Accepted: 28 July 2021

Published: 30 July 2021

Publisher's Note: MDPI stays neutral with regard to jurisdictional claims in published maps and institutional affiliations.

Copyright: (c) 2021 by the authors. Licensee MDPI, Basel, Switzerland. This article is an open access article distributed under the terms and conditions of the Creative Commons Attribution (CC BY) license (https:/ / creativecommons.org/licenses/by/ $4.0 /)$.

\begin{abstract}
Despite the toxicity and health risk characteristics of formaldehyde (FA), it is currently used as a cytological fixative and the definition of safe exposure levels is still a matter of debate. Our aim was to investigate the alterations in both oxidative and inflammatory status in a hospital working population. The 68 workers recruited wore a personal air-FA passive sampler, provided a urine sample to measure $15-\mathrm{F}_{2 \mathrm{t}}$-Isoprostane $\left(15-\mathrm{F}_{2 \mathrm{t}}\right.$-IsoP) and malondialdehyde (MDA) and a blood specimen to measure tumour necrosis factor $\alpha(\mathrm{TNF} \alpha)$. Subjects were also genotyped for GSTT1 (Presence/Absence), GSTM1 (Presence/Absence), CYP1A1 exon 7 (A > G), and IL6 ( $-174, \mathrm{G}>\mathrm{C})$. Workers were ex post split into formalin-employers $\left(57.3 \mu \mathrm{g} / \mathrm{m}^{3}\right)$ and non-employers $\left(13.5 \mu \mathrm{g} / \mathrm{m}^{3}\right)$. In the formalin-employers group we assessed significantly higher levels of $15-\mathrm{F}_{2 \mathrm{t}}$-IsoP, MDA and TNF $\alpha$ $(<0.001)$ in comparison to the non-employers group. The air-FA levels turned out to be positively correlated with $15-\mathrm{F}_{2 t}$-IsoP $(p=0.027)$ and MDA $(p<0.001)$. In the formalin-employers group the MDA level was significantly higher in GSTT1 Null ( $p=0.038)$, GSTM1 Null $(p=0.031)$, and CYP1A1 exon 7 mutation carrier $(p=0.008)$ workers, compared to the wild type subjects. This study confirms the role of FA in biomolecular profiles alterations, highlighting how low occupational exposure can also result in measurable biological outcomes.
\end{abstract}

Keywords: formaldehyde; 15- $\mathrm{F}_{2 \mathrm{t}}$-isoprostane; malondialdehyde; TNF $\alpha$; GSTT1; GSTM1; occupational health

\section{Introduction}

The exposure to airborne pollutants can result in harmful health effects, depending on the chemical agents, the time of exposure, and the individual susceptibility [1]. Several studies have focused on hospital workers and their occupational risks [1-5], e.g., operating theatre nurses and pathologists, including those who are chronically exposed to formaldehyde (FA) [6-8].

FA inhalation has been associated with several toxic effects: low exposure levels (0.1 ppm) can irritate the eyes, nose and upper respiratory airways, while high concentrations may result in pulmonary function impairment and asthma $[9,10]$. Prolonged exposure to FA has been also associated with nasopharyngeal cancer [11,12] and leukaemia [12,13], and there is limited evidence of a possible association of this compound with sinonasal cancer [14]. In this context, the International Agency for Research on Cancer (IARC) classifies FA as "carcinogenic to humans (Group 1)" [15].

Despite its harmful characteristics, FA is still widely used in pathology wards, where it has been used as fixative for almost 100 years due to its unique ability in preserving cell 
and tissue morphology $[16,17]$. Hence, the long-standing concerns over the adverse health effects related to FA exposure [18] in this population.

Workers employed in settings where FA or FA-containing products are made or used may be exposed to such chemicals, mainly by inhalation or skin contact [19]. In order to protect their health, the American Conference of Governmental Industrial Hygienists (ACGIH) updated in 2016 the threshold limit of exposure. Indeed, after having recommended only a threshold limit value-ceiling (TLV-C) of $370 \mu \mathrm{g} / \mathrm{m}^{3}$ since 1992, the limits were updated introducing a "time-weighted average" threshold limit value (TLV-TWA) at $120 \mu \mathrm{g} / \mathrm{m}^{3}$ and a "short-term exposure limit" (TLV-STEL) at $370 \mu \mathrm{g} / \mathrm{m}^{3}$ [20]. The European Union (EU) Scientific Committee for Occupational Exposure Limits (SCOEL) proposed a FA 8-h OEL of $370 \mu \mathrm{g} / \mathrm{m}^{3}$ and a 15-min STEL of $740 \mu \mathrm{g} / \mathrm{m}^{3}$ [21].

The EU Carcinogens and Mutagens Directive of 2019 recently set a Binding Occupational Exposure Limit (BOEL) at $0.37 \mathrm{mg} / \mathrm{m}^{3}(0.3 \mathrm{ppm})$ for long-term exposure (8-h time-weighted average) and of $0.74 \mathrm{mg} / \mathrm{m}^{3}(0.6 \mathrm{ppm})$ for 15-min exposure. Moreover, a specific 8 -h limit value of $0.62 \mathrm{mg} / \mathrm{m}^{3}(0.5 \mathrm{ppm})$ was introduced for the healthcare, funeral and embalming sectors, which will be valid until July 2024 [22].

A recent review on the management of FA pollution in pathology wards [23] highlighted that most studies had suggested improving the exhaustion ventilation systems and to use appropriate personal protective equipment (PPE). In the same regards, other research demonstrated the effectiveness of technological approaches, such as photocatalyst and vacuum sealing technologies, alongside with the use of alternative fixatives to formalin [23]. However, due the current lack of an effective alternative chemical, the use of formalin is still needed, making it necessary to arrange various measures to control workers' exposure, such as the isolation of activities producing greater emissions and the adoption of new standard procedures in order to reduce the number of samples soaked into formalin [22].

The possible mechanisms underlying the FA-induced long-term effects include inflammation, oxidative stress (OS), and apoptosis [24]. Indeed, FA is a powerful trigger of inflammation in the lower airways [25]; several signalling mechanisms, such as the MAPK and NF-kb pathways, have been proposed alongside the FA-induced increase in intracellular reactive oxygen species (ROS) [26]. This condition of imbalance between an excess of oxidant compounds and insufficient antioxidant defences [27], can lead to oxidative damage to biomolecules, including proteins, lipids, and nucleic acids, for example through lipid peroxidation [28]. The alteration of oxidative status is frequently studied through specific biomarkers, such as malondialdehyde (MDA) and $\mathrm{F}_{2}$-isoprostanes ( $\mathrm{F}_{2}$-IsoPs) as measure of lipid peroxidation [29-31]. In order to protect themselves against hostile oxidative environments, living organisms evolved several antioxidant defenses, including antioxidant enzymes as well as non-enzymatic ROS scavengers [32]. One of the main non-enzymatic antioxidants is glutathione (GSH), which is able to scavenge ROS and thus decrease OS [26,33]. This compound is also involved in FA-absorbed oxidation, since dehydrogenation of FA requires GSH [34,35].

ROS and antioxidants could also influence the immune system [36]. Indeed, the OS condition could lead to an increase in airway and systemic inflammation associated either to $\mathrm{T}_{\mathrm{H}} 1$ or $\mathrm{T}_{\mathrm{H}} 2$ cytokine production [37]. Specifically, interleukin (IL)- 6 and tumour necrosis factor-alpha (TNF- $\alpha$ ) play a key role in the immune and inflammatory response and several studies have evaluated the alteration of their levels following FA exposure, albeit with contrasting results [38-42].

Simultaneously, several genetic pathways have evolved for minimizing the effects of environmental exposures [43]. The heritable variability of these genes may be associated with an altered efficiency of the processes in which they are involved [43]. Among these, the enzymes belonging to the glutathione S-transferase (GST) and cytochrome P450 (CYP) families take part in a two-step detoxification process of a wide spectrum of environmental xenobiotics [44,45]. Moreover, the vast majority of GSTs' functions are associated with detoxification or anti-oxidation processes: structural changes in these molecules can lead to a high variation in their enzymatic activity, resulting thus in OS intensification which 
can lead to an increase in susceptibility to chronic diseases such as hypertension and cancer [46]. Similarly, cytokine genes can also be polymorphic, resulting in an alteration of the overall expression and secretion of these molecules, partly explaining the interindividual differences in immune responsiveness [1].

Thus, the aim of this study is to evaluate the systemic oxidative and inflammatory status alteration in a hospital working population routinely exposed to air-FA. Moreover, to better understand the role of inter-individual differences in the exposure-related outcomes, all participants were genotyped for polymorphisms involved in xenobiotic metabolism and in cytokine production. We selected the following polymorphisms: CYP1A1 exon 7 $(A>G)$, which is involved in phase I metabolic pathways, GSTT1 (Presence/Absence) and GSTM1 (Presence/Absence), which are involved in phase II reactions, and, finally, TNF- $\alpha$ $(-308, G>A)$ and $I L-6(-174, G>C)$ to evaluate the possible role of an alteration in the production of cytokines involved in long-term inflammation processes. Indeed, our interest is to highlight the susceptibility biomarkers relevant in occupational studies and, more specifically, their role in influencing the oxidative and inflammatory status.

\section{Materials and Methods}

\subsection{Study Population}

Sixty-eight workers variously exposed to FA (nurses, health care assistants, laboratory technicians and pathologists) were recruited at "Città della Salute e della Scienza" (Turin, Italy), during the same sampling campaign described in our previous study [7]. Only those subjects who agreed to give a blood sample were considered eligible for the purpose of this study. In accordance with the 2013 Declaration of Helsinki, all subjects received detailed information about the project and gave their informed consent before the participation. The research protocol was approved by the Bioethical Committee of University of Turin.

Each subject: (1) wore a personal air-FA sampler for an 8-h working shift; (2) completed a standardised questionnaire; (3) provided biological samples for the quantification of OS and inflammatory biomarkers: a spot of urine for the quantification of OS biomarkers (15- $\mathrm{F}_{2 \mathrm{t}}$-IsoP, and MDA) and creatinine (CREA), and a fresh blood sample to measure TNF $\alpha$ and single nucleotide polymorphisms (SNPs) frequency.

Workers involved in this study were employed in tasks involving FA use in rotation and were classified ex post as "formalin-employers" or "non-employers", according to the use of formalin by each volunteer during the sampling day. The exposure level measured in the formalin-employers group could be considered as an approximation of the mean exposure level of the period in which they employed FA-based chemicals. Conversely, the exposure levels measured in the subject group not employing formalin could be representative of the general indoor air-FA level.

\subsection{Questionnaire, Personal Air-FA Exposure Assessment, and Biological Measurements}

The questionnaire and its administration, air-FA sampling and the urine spot collection and storage have been previously described [7].

Briefly, a standardised questionnaire was administered to all workers to collect information about individual factors (sex, age, BMI), working conditions (task, FA exposure, working years) and lifestyle factors (smoking).

To assess the individual (personal) exposure to air-FA, each volunteer wore a radial diffusive personal passive sampler during an 8-h working shift.

During the same day, each subject also provided a specimen of blood and a spot of urine in order to obtain systemic measurement of the studied alterations, given the short half-life of FA, which is rapidly metabolised after entering in the body.

\subsubsection{Personal Air-FA Exposure}

Given the high variability in FA exposure according to the different tasks of the subjects enrolled, the individual exposure was quantified, for each subject, using a radial symmetry diffusive sampler (Radiello ${ }^{\circledR}$, ICS Maugeri SpA, Pavia, Italy) (https:// radiello. 
$\mathrm{com} /$, accessed on 8 June 2021), as described in previous studies [47,48]. The sampler was clipped near the volunteers' breathing zone during a whole working shift, in order to assess the FA concentration in the air inhaled by each worker.

Briefly, the photoprotective diffusive body of the sampler, operating in diffusive mode, was equipped with sorbent cartridges consisting in a stainless-steel mesh tube filled with Florisil ${ }^{\mathrm{TM}}$ coated with 2,4-dinitrophenylhydrazine (2,4-DNPH). The reaction between airborne aldehydes and 2,4-DNPH leads to the production of the corresponding 2,4-dinitrophenylhydrazone, that can be extracted by $2 \mathrm{~mL}$ of acetonitrile (Merck, Milan, Italy), directly inserted in each cartridge tube and then stirred for $30 \mathrm{~min}$. The solution obtained was subsequently filtered and analysed by reverse-phase HPLC with a UV detector set at a wavelength of $365 \mathrm{~nm} .10-50 \mu \mathrm{L}$ of the solution were injected and eluted at flow of $1.9 \mathrm{~mL} / \mathrm{min}$. An isocratic elution was performed with acetonitrile/water 38:62 $v / v$ for $10 \mathrm{~min}$, up to acetonitrile/water 75:25 $v / v$ in $10 \mathrm{~min}$, and reverse gradient to acetonitrile/water 38:62 $v / v$ in $5 \mathrm{~min}$. FA was quantified by high performance liquid chromatography (HPLC) according to the NIOSH method No. 2016. The quantification limit was twice the detection limit: $0.10 \mu \mathrm{g} / \mathrm{mL}$ and $0.05 \mu \mathrm{g} / \mathrm{mL}$, respectively. The $\mathrm{CV}$ values were $<5 \%$.

\subsubsection{OS Measurement}

15- $\mathrm{F}_{2 \mathrm{t}}$-IsoP and MDA urinary concentrations were quantified by competitive E.L.I.S.A. kit (Urinary Isoprostane ELISA Kit, Oxford Biomedical Research, Rochester Hills, MI, USA and TBARS assay kit, Abnova, Taipei, Taiwan, respectively) performed according to the manufacturer's instructions. Urinary creatinine was determined by the kinetic Jaffé procedure [49] to normalise the urinary excretion rate of $15-\mathrm{F}_{2 \mathrm{t}}$-IsoP.

Briefly, to measure the total fraction $15-\mathrm{F}_{2 \mathrm{t}}-\mathrm{IsoP}$, urine samples were incubated for $2 \mathrm{~h}$ at $37^{\circ} \mathrm{C}$ with $\beta$-glucuronidase and then mixed with an enhanced dilution buffer to eliminate interferences due to non-specific binding. The assay measures the $15-\mathrm{F}_{2 \mathrm{t}}-\mathrm{IsoP}$ in samples or standards competing with $15-\mathrm{F}_{2 \mathrm{t}}$-IsoP conjugated to horseradish peroxidase (HRP) for binding to a polyclonal antibody specific for $15-\mathrm{F}_{2 \mathrm{t}}$-IsoP coated on the microplate through colour development when the substrate is added. The colour intensity is inversely proportional to the amount of unconjugated analyte in samples or standards. The LOD was $0.08 \mathrm{ng} / \mathrm{mL}$.

The Thiobarbituric Acid Reactive Substances (TBARS) assay, instead, is based on the quantification of the MDA-TBA adduct formed by MDA and TBA under high temperature $\left(99-100{ }^{\circ} \mathrm{C}\right.$ ) and acidic conditions. The reaction between one molecule of MDA and 2 molecules of 2-thiobarbituric acid leads to the formation of a chromophore and can be measured colorimetrically at 530-540 nm.

\subsubsection{Blood Sample Collection and Inflammatory Biomarkers}

Blood samples were obtained by venepuncture $(5-10 \mathrm{~mL})$ and collected in heparinised Vacutainer ${ }^{\circledR}$ (Becton, Dickinson and Company, Franklin Lakes, NJ, USA).

TNF- $\alpha$ was quantified using a Human Soluble Cytokine Receptor Panel kit (MILLIPLEX ${ }^{\circledR}$ MAP, Merck, Milan, Italy). This assay is based on the Luminex xMAP ${ }^{\circledR}$ technology, a multiplex technology capable of performing immunoassays on the surface of fluorescentcoded magnetic beads known as MagPlex ${ }^{\circledR}-\mathrm{C}$ microspheres. Luminex uses proprietary techniques to internally colour-code microspheres with two fluorescent dyes. Through precise concentrations of these dyes, distinctly coloured bead sets of $5005.6 \mu \mathrm{m}$ polystyrene microspheres or $806.45 \mu \mathrm{m}$ magnetic microspheres coated with a specific capture antibody are created. After the bead captures an analyte from a test sample, a biotinylated detection antibody is introduced. Streptavidin-PE conjugate, the reporter molecule, is added to the mixture to allow the reaction conclusion on the surface of each microsphere. Each microsphere is identified. Our results were quantified based on fluorescent reporter signals [50]. 


\subsubsection{DNA Extraction and Genotyping}

Genomic DNA was extracted from white blood cells isolated with the Ficoll separation method and stored at $-140^{\circ} \mathrm{C}$. Vials containing whole blood were centrifuged at $1000 \mathrm{rpm}$ for $10 \mathrm{~min}$, with the centrifuge brake set to off. Plasma was aspired with a venturi pump, leaving about 1-2 $\mathrm{mL}$ of plasma in the vial. The remaining content was transferred in a Falcon tube and the pellet was diluted 1:2 with RPMI-1640 medium (Thermo Fisher Scientific, Inc., Waltham, MA, USA) or PBS (Thermo Fisher Scientific, Inc., Waltham, MA, USA) previously heated in a thermostatic bath. The tube content was then transferred drop by drop, at least in the first steps, in a clean Falcon tube containing 10-15 mL of Biocoll solution previously heated in a thermostatic bath. Falcon tubes were centrifuged for 25-30 min at 1700-1800 rpm with the centrifuge brake off. The opalescent ring formed containing lymphocytes and monocytes was transferred in a clean tube. The washing step was performed with RPMI- 1640 medium, adding $5 \mathrm{~mL}$ of medium drop by drop, mixing by inversion 1-2 times and then adding medium up to $30-50 \mathrm{~mL}$. Tubes were centrifuged for 8-10 min at $1400 \mathrm{rpm}$ with centrifuge brake off. The supernatant was removed by aspiration with a Venturi pump and the pellet was gently re-suspended by hitting the bottom of the tube. If the supernatant was turbid, RPMI-1640 medium was again added in tubes with samples up to $15-20 \mathrm{~mL}$; samples were mixed by inversion and centrifuged 8-10 min at $1200 \mathrm{rpm}$ with the centrifuge brake off. The supernatant was removed, the pellet re-suspended and $1 \mathrm{~mL}$ of freezing medium (50\% inactivated FBS (Thermo Fisher Scientific, Inc., Waltham, MA, USA), 40\% RPMI-1640 medium, 10\% DMSO (Merck, Milan, Italy)) was then added drop by drop to each sample. Cells were resuspended, and $1 \mathrm{~mL}$ of the sample was transferred in a cryovial. Vials were stored at $-80^{\circ} \mathrm{C}$ and then at $-140{ }^{\circ} \mathrm{C}$. DNA extraction was conducted by using a salting-out procedure: white blood cells were centrifuged at 14,000 rpm and the pellet was resuspended in a solution consisting of $340 \mu \mathrm{L}$ white cell lysis buffer (10 mM Tris pH 7.6 (Merck, Milan, Italy); 10 mM EDTA (Merck, Milan, Italy) and $50 \mathrm{mM} \mathrm{NaCl}$ (Merck, Milan, Italy)), $10 \mu \mathrm{L}$ of SDS 10\% (Merck, Milan, Italy) and $30 \mu \mathrm{L}$ of proteinase $\mathrm{K}$ (Merck, Milan, Italy). After incubation at $55^{\circ} \mathrm{C}$ for $30 \mathrm{~min}, 200 \mu \mathrm{L}$ of saturated sodium acetate was added to the solution. The samples were vigorously shaken and centrifuged at 14,000 rpm for $5 \mathrm{~min}$. Subsequently, $0.5 \mathrm{~mL}$ of isopropanol for DNA precipitation were added to the supernatant solution and, after centrifugation at $14,000 \mathrm{rpm}$ for $1 \mathrm{~min}, 0.5 \mathrm{~mL}$ of $70 \%$ ethanol was added to remove salt from the pellet. After 30-60 min at room temperature, the pellet was resuspended in $50 \mu \mathrm{L}$ of ultrapure distilled water.

All subjects were genotyped for GSTT1, GSTM1, CYP1A1 exon 7, TNF- $\alpha$ and IL-6 by using primers and methodologies as described in Table 1. PCR reactions were performed in a $25 \mu \mathrm{L}$ volume containing about $10 \mathrm{ng}$ DNA (template), with a final concentration of 1X Reaction Buffer (Thermo Fisher Scientific, Inc., Waltham, MA, USA), $1.5 \mathrm{mM}$ of $\mathrm{MgCl}_{2}$ (Thermo Fisher Scientific, Inc., Waltham, MA, USA), 5\% of DMSO (Thermo Fisher Scientific, Inc., Waltham, MA, USA), $250 \mu \mathrm{M}$ of dNTPs (Thermo Fisher Scientific, Inc., Waltham, MA, USA), $0.5 \mu \mathrm{M}$ of each primer, and $1 \mathrm{U} /$ sample of Taq DNA polymerase (Thermo Fisher Scientific, Inc., Waltham, MA, USA). Cycles were set as follows: 35 cycles, $1 \mathrm{~min}$ at $95^{\circ} \mathrm{C}$, $1 \mathrm{~min}$ at $60-65^{\circ} \mathrm{C}$ (depending on the gene polymorphism, Table 1 ), 1 min at $72{ }^{\circ} \mathrm{C}$, and a final extension step $10 \mathrm{~min}$ at $72{ }^{\circ} \mathrm{C}$. Amplification products were detected by ethidium bromide (Merck, Milan, Italy) staining after 3\% agarose gel (Società Italiana Chimici, Rome, Italy) electrophoresis.

\subsection{Statistical Analysis}

Statistical analyses were performed by SPSS Statistics 27 (IBM SPSS Statistics, New York, NY, USA) and RStudio (RStudio Desktop 1.2.5042, RStudio Inc., Boston, MA, USA). A Shapiro-Wilk test was performed to assess the normality of the distributions.

Descriptive analyses were performed by using $\chi^{2}$ or Fisher tests for categorical variables (sex, smoking, task, working years, and gene polymorphisms) and a Wilcoxon test or $\mathrm{t}$-test for continuous variables (age, BMI, FA, $15-\mathrm{F}_{2 \mathrm{t}}-\mathrm{IsoP}$, MDA, and TNF- $\alpha$ ), as appropriate. Non-parametric correlations were assessed by Spearman's test to investigate 
the correlation between biomarkers and FA exposure, and between biomarkers themselves. Non-parametric comparison of biological and environmental variables between formalin-employers and non-employers groups were performed by the Mann-Whitney or Kruskall-Wallis tests. Boxplots were drawn to show the difference of MDA levels between formalin-employers and non-employers according to GSTT1, GSTM1, and CYP1A1 polymorphisms.

Table 1. Description of primer sequence, annealing temperature, methodology employed and PCR product size (bp).

\begin{tabular}{|c|c|c|c|c|c|c|c|}
\hline Gene & $\begin{array}{l}\text { Polymorphism } \\
\text { NCBI }\end{array}$ & $\begin{array}{c}\text { Main } \\
\text { Function } \\
\text { Protein }\end{array}$ & Sequence & $\stackrel{\mathrm{T}}{\left({ }^{\circ} \mathrm{C}\right)}$ & Methodology & $\begin{array}{c}\text { PCR } \\
\text { Product } \\
\text { Size (bp) }\end{array}$ & Reference \\
\hline $\begin{array}{l}\text { CYP1A1 } \\
(\mathrm{A}>\mathrm{G})\end{array}$ & rs1048943 & $\begin{array}{l}\text { Phase-I } \\
\text { metabolic } \\
\text { enzyme }\end{array}$ & $\begin{array}{c}\text { 5'-AAGACCTCCCAGCGGGCAAT-3' }^{\prime} \\
\text { 5'-AAGACCTCCCAGCGGGCAAC-3' }^{\prime} \\
\text { 5'-CTCTGGTTACAGGAAGCTAT-3'3 }^{\prime}\end{array}$ & 60 & ARMS-PCR & 162 & [51] \\
\hline $\begin{array}{c}\text { GSTT1 } \\
\text { (Presence/ } \\
\text { Absence) }\end{array}$ & rs1601993659 & $\begin{array}{l}\text { Phase-II } \\
\text { metabolic } \\
\text { enzyme }\end{array}$ & $\begin{array}{c}\text { 5'-TTCCTTACTGGTCCTCACATCTC-3' } \\
5^{\prime} \text {-TCACCGGATCATGGCCAGCA-3' }\end{array}$ & 63 & PCR & 480 & [52] \\
\hline $\begin{array}{l}\text { GSTM1 } \\
\text { (Presence/ } \\
\text { Absence) }\end{array}$ & rs1183423000 & $\begin{array}{l}\text { Phase-II } \\
\text { metabolic } \\
\text { enzyme }\end{array}$ & $\begin{array}{l}\text { 5-CTGGATTGTAGCAGATCATGC-3' } \\
\text { 5'-CTGCCCTACTTGATTGATGGG-3' }^{\prime} \text {-CTGG }\end{array}$ & 65 & PCR & 273 & [53] \\
\hline $\begin{array}{c}T N F-\alpha \\
(-308, G>A) \\
\text { Antisense } \\
\text { primer } \\
\text { G-sense primer } \\
\text { A-sense primer }\end{array}$ & rs1800629 & $\begin{array}{l}\text { Pro- } \\
\text { inflammatory }\end{array}$ & $\begin{array}{l}\text { 5'-TCTCGGTTTCTTCTCCATCG-3' } \\
\text { 5'-ATAGGTTTTGAGGGGCATGG-3' } \\
\text { 5-AATAGGTTTTGAGGGGCATGA-3' }\end{array}$ & 60 & ARMS-PCR & 184 & [54] \\
\hline $\begin{array}{c}I L-6 \\
(-174, \mathrm{G}>\mathrm{C}) \\
\text { Antisense } \\
\text { primer } \\
\text { G-sense primer } \\
\text { C-sense primer }\end{array}$ & rs1800796 & $\begin{array}{l}\text { Pro- } \\
\text { inflammatory }\end{array}$ & $\begin{array}{l}\text { 5'-TCGTGCATGACTTCAGCTTTA-3'3 } \\
5^{\prime} \text {-AATGTGACGTCCTTTAGCATG-3' } \\
5^{\prime} \text {-AATGTGACGTCCTTTAGCATC-3' }\end{array}$ & 60 & ARMS-PCR & 190 & [55] \\
\hline
\end{tabular}

\section{Results}

The general description of the sample was described in the previous paper [7], while the following descriptive analyses are referred to FA exposure (Tables 2 and 3).

Table 2. Characteristics of the sampled population presented as formalin-employers and non-employers groups. Differences between formalin-employers and non-employers groups were tested by $\chi^{2} /$ Fisher tests as appropriate and Wilcoxon tests for categorical and continuous variables, respectively.

\begin{tabular}{|c|c|c|c|c|c|}
\hline \multirow{2}{*}{ Characteristics } & \multicolumn{2}{|c|}{ Formalin-Employers $(n=23)$} & \multicolumn{2}{|c|}{ Non-Employers $(n=45)$} & \multirow{2}{*}{$p$-Value } \\
\hline & \multicolumn{2}{|c|}{$n(\%)$} & \multicolumn{2}{|c|}{$n(\%)$} & \\
\hline Sex & & & & & \multirow[b]{3}{*}{0.522} \\
\hline Male & \multirow{2}{*}{\multicolumn{2}{|c|}{$\begin{array}{c}5(21.7) \\
18(78.3)\end{array}$}} & \multirow{2}{*}{\multicolumn{2}{|c|}{$\begin{array}{c}7(15.6) \\
38(84.4)\end{array}$}} & \\
\hline Female & & & & & \\
\hline \multicolumn{6}{|l|}{ Smoking } \\
\hline Yes & \multirow{2}{*}{\multicolumn{2}{|c|}{$\begin{array}{c}7(30.4) \\
16(69.6)\end{array}$}} & \multirow{2}{*}{\multicolumn{2}{|c|}{$\begin{array}{l}12(26.7) \\
33(73.3)\end{array}$}} & \multirow[b]{2}{*}{0.780} \\
\hline No & & & & & \\
\hline \multicolumn{6}{|l|}{ Task } \\
\hline Healthcare assistant & \multicolumn{2}{|c|}{$4(17.4)$} & \multicolumn{2}{|c|}{$11(24.4)$} & \\
\hline Nurse & \multicolumn{2}{|c|}{$7(30.4)$} & \multicolumn{2}{|c|}{$20(44.4)$} & \\
\hline Laboratory technician & \multicolumn{2}{|c|}{$7(30.4)$} & \multicolumn{2}{|c|}{$12(26.7)$} & 0.133 \\
\hline Pathologist & \multicolumn{2}{|c|}{$5(21.7)$} & \multicolumn{2}{|c|}{$2(4.4)$} & \\
\hline \multicolumn{6}{|l|}{ Working years } \\
\hline$<5$ & \multicolumn{2}{|c|}{$3(13.0)$} & \multicolumn{2}{|c|}{$5(11.1)$} & \\
\hline $5-10$ & \multirow{2}{*}{\multicolumn{2}{|c|}{$\begin{array}{c}5(21.7) \\
15(65.2)\end{array}$}} & & & 0.973 \\
\hline \multirow[t]{2}{*}{$>10$} & & & \multicolumn{2}{|c|}{$\begin{array}{l}10(22.2) \\
30(66.7)\end{array}$} & \\
\hline & Median & IQR & Median & IQR & \\
\hline Age (years) & 44.00 & 14.00 & 49.00 & 13.00 & 0.369 \\
\hline $\mathrm{BMI}\left(\mathrm{kg} / \mathrm{m}^{2}\right)$ & 23.44 & 4.20 & 23.40 & 7.32 & 0.429 \\
\hline
\end{tabular}


Table 3. FA exposure, biomarker measurements, and polymorphism frequencies of the sampled population presented as formalin-employers and non-employers groups. Differences between formalin-employers and non-employers groups were tested by $\chi^{2} /$ Fisher tests as appropriate and Wilcoxon tests for categorical and continuous variables, respectively.

\begin{tabular}{|c|c|c|c|c|c|}
\hline \multirow{2}{*}{ Parameters } & \multicolumn{2}{|c|}{ Formalin-Employers $(n=23)$} & \multicolumn{2}{|c|}{ Non-Employers $(n=45)$} & \multirow{2}{*}{$p$-Value } \\
\hline & Median & IQR & Median & IQR & \\
\hline $\mathrm{FA}\left(\mu \mathrm{g} / \mathrm{m}^{3}\right)$ & 57.3 & 125.9 & 13.5 & 12.7 & $<0.001$ \\
\hline $15-\mathrm{F}_{2 \mathrm{t}}$-IsoP (ng/mg CREA) & 16.06 & 14.98 & 2.16 & 2.67 & $<0.001$ \\
\hline $\operatorname{MDA}(\mu \mathrm{M})$ & 2.29 & 0.67 & 1.25 & 0.64 & $<0.001$ \\
\hline \multirow[t]{2}{*}{$T N F-\alpha(\mathrm{pg} / \mathrm{mL})$} & 15.35 & 16.51 & 11.59 & 7.31 & 0.023 \\
\hline & \multicolumn{2}{|c|}{$n(\%)$} & \multicolumn{2}{|c|}{$n(\%)$} & \\
\hline \multicolumn{6}{|l|}{ GSTT1 } \\
\hline GSTT+ & \multirow{2}{*}{\multicolumn{2}{|c|}{$\begin{array}{c}15(65.2) \\
8(34.8)\end{array}$}} & \multirow{2}{*}{\multicolumn{2}{|c|}{$\begin{array}{c}38(84.4) \\
7(15.6)\end{array}$}} & \\
\hline GSTT Null & & & & & 0.120 \\
\hline GSTM1 & & & & & \\
\hline GSTM+ & \multirow{2}{*}{\multicolumn{2}{|c|}{$\begin{array}{c}16(69.6) \\
7(30.4)\end{array}$}} & \multicolumn{2}{|c|}{34 (75.6) } & \multirow[b]{2}{*}{0.772} \\
\hline GSTM Null & & & & & \\
\hline \multicolumn{6}{|l|}{ CYP1A1 } \\
\hline wt & \multirow{2}{*}{\multicolumn{2}{|c|}{$\begin{array}{c}15(65.2) \\
8(34.8)\end{array}$}} & \multicolumn{2}{|c|}{32 (71.1) } & \multirow[b]{2}{*}{0.782} \\
\hline mutation carrier & & & & & \\
\hline \multicolumn{6}{|l|}{$T N F-\alpha$} \\
\hline wt & \multirow{2}{*}{\multicolumn{2}{|c|}{$\begin{array}{c}18(78.3) \\
5(21.7)\end{array}$}} & \multirow{2}{*}{\multicolumn{2}{|c|}{$\begin{array}{l}30(66.7) \\
15(33.3)\end{array}$}} & \multirow[b]{2}{*}{0.405} \\
\hline mutation carrier & & & & & \\
\hline \multicolumn{6}{|l|}{$I L-6$} \\
\hline wt & \multirow{2}{*}{\multicolumn{2}{|c|}{$\begin{array}{c}15(65.2) \\
8(34.8)\end{array}$}} & \multirow{2}{*}{\multicolumn{2}{|c|}{$\begin{array}{l}32(71.1) \\
13(28.9)\end{array}$}} & \multirow{2}{*}{0.782} \\
\hline mutation carrier & & & & & \\
\hline
\end{tabular}

wt, wild type.

As expected, the difference in FA levels between formalin-employers and non-employers proved to be highly significant $(p<0.001)$. Concerning biomarkers, the comparison between formalin-employers and non-employers revealed a significant alteration in both oxidative and inflammatory status. Specifically, significant differences were found in $15-\mathrm{F}_{2 \mathrm{t}}$-IsoP $(p<0.001)$, MDA $(p<0.001)$, and TNF- $\alpha(p=0.023)$. Conversely, no differences were found concerning confounding factors such as gender, age, BMI, tasks, working years and smoking habits, nor in the frequency of polymorphisms' distribution.

The air-FA concentration was significantly and positively correlated with $15-\mathrm{F}_{2 \mathrm{t}}$-Isop (Spearman's rho $=0.269, p=0.027$ ) and MDA (Spearman's rho $=0.647, p<0.001)$. Among biomarkers a correlation was found between 15- $\mathrm{F}_{2 \mathrm{t}}$-Isop and MDA (Spearman's rho = 0.471, $p<0.001)$ and MDA and TNF- $\alpha$ (Spearman's rho $=0.299, p=0.013$ ).

Regarding the gene polymorphisms, GSTT1 Null subjects had higher MDA concentration than GSTT1+ in both formalin-employers and non-employers $t=2.220, p=0.038$ and $\mathrm{t}=2.827, p=0.007$, respectively Figure $1 \mathrm{~A}$ ).

In formalin-employers, higher MDA levels were found in subjects GSTM1 Null $(\mathrm{t}=0.679, p=0.031$, Figure 1B) compared to GSTM1+ and in those who carried at least one mutated allele for the CYP1A1 gene $(U=20.50, p=0.008$, Figure $1 C)$ in comparison with the wt. The additional comparison between the wt and carriers of mutation for the other biomarkers did not provide any significant results. 


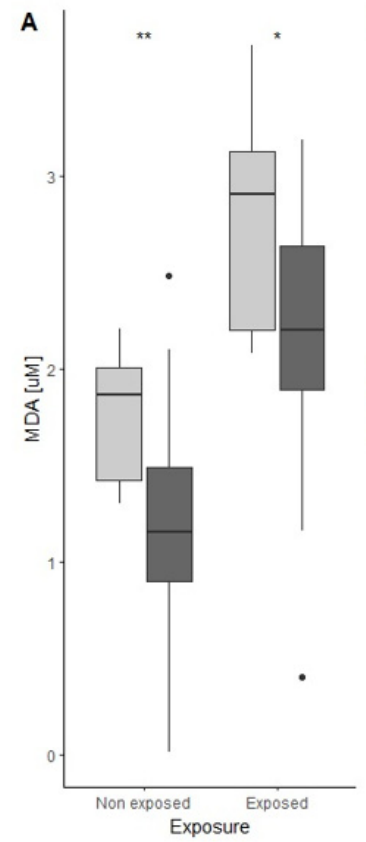

GSTT1 由 GST1 Null 由 GST1+

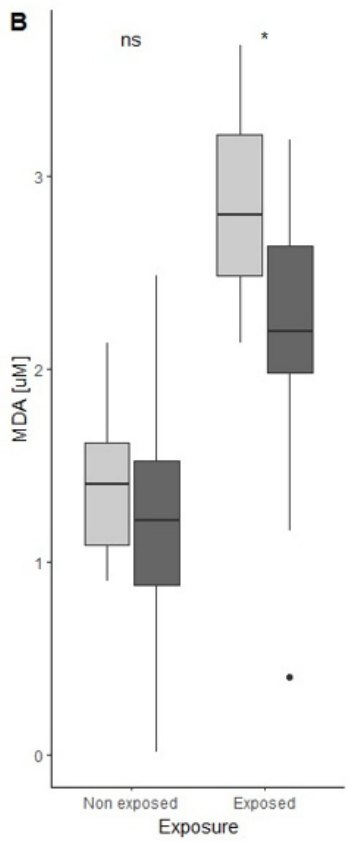

GSTM1 追 GSTM1 Null G GTM1+

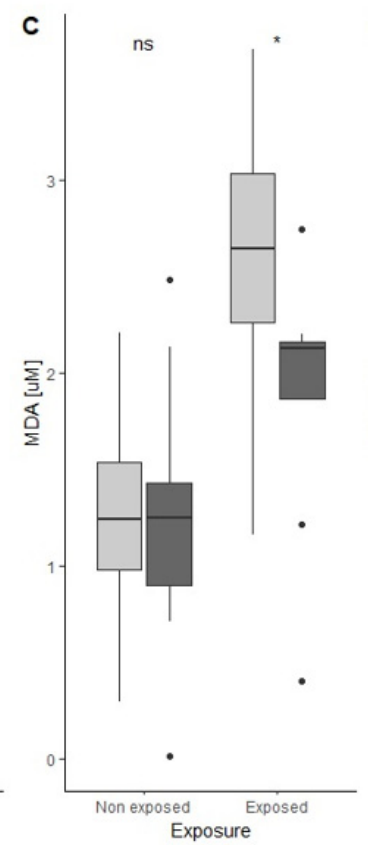

CYP1A1 追 wt mutation carrier

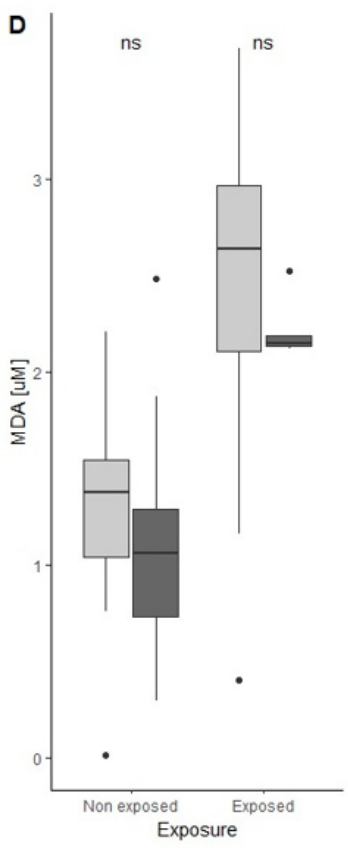

TNF-a 审 wt 官 mutation carrier

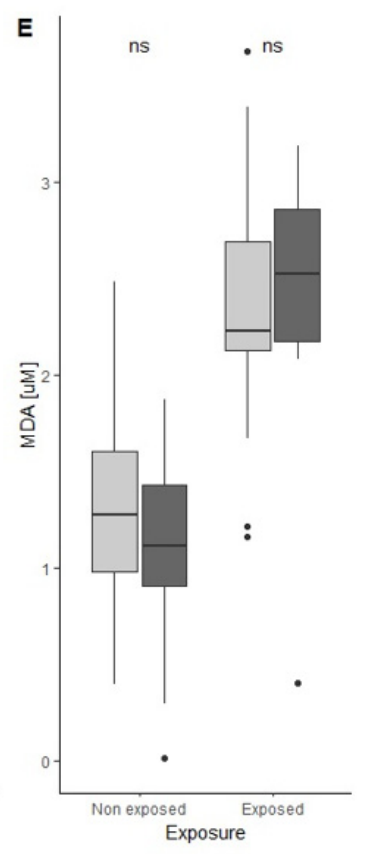

IL-6 审 wt 早 mutation carrier

Figure 1. Boxplot of MDA levels in formalin-employers and non-employers according to the five polymorphisms analysed: (A) GSTT1, (B) GSTM1, (C) CYP1A1, (D) TNF- $\alpha$, (E) IL-6. In each panel the non-employers data are depicted on the left side, while the formalin-employers data are on the right. In each group, the boxplot in light grey shows the mutation carriers for the selected genes, while the boxplot in dark grey is related to the wt. ${ }^{*}: p<0.05,{ }^{* *}: p<0.01$, ns: not significant, dots represent the outliers.

\section{Discussion}

FA has been the most popular fixative in histology: the ease in use, the low cost and the variety of techniques that can be performed following fixation are only some of the properties which made widespread the usage of this chemical [56]. Nevertheless, the health and safety risks associated with formalin exposure are still a matter of concern [57].

The main aim of this study was to investigate wide range of outcomes in terms of alteration of the oxidative and inflammatory status related to occupational exposure to FA, considering the possible role of genetic polymorphisms in modulating the individual response.

The FA metabolism includes several oxidation steps that could lead to ROS generation [58], and, in turn, to the alteration of exposed subjects' biomolecular profiles, as confirmed in this study.

Oxidative stress and inflammatory biomarkers levels must be interpreted as the outcome of the metabolic pathways of the days before sampling.

Among formalin-employers we found a significant alteration in the systemic oxidative status, highlighted by significantly higher urinary concentration of $15-\mathrm{F}_{2 \mathrm{t}}-\mathrm{IsoP}$ and MDA than in non-employers. In line with our results, many studies in literature reported interesting data demonstrating systemic adverse effects following FA exposure in occupational settings $[4,59,60]$.

A huge number of studies to date have demonstrated the role of ROS in the pathogenesis of chronic diseases including cancer. ROS sources could be both endogenous, from mitochondria, peroxisomes or inflammatory cell activation, and exogenous, caused by environmental agents, radiations, pharmaceuticals, or industrial chemicals. When an excess of ROS is produced for a long time, resulting in a condition known as OS, cellular structure and functions may be affected by significant damages, which, in turn, may induce somatic mutations and neoplastic transformation $[61,62]$. 
The air-FA concentration measured in the workers' breathing zone resulted positively correlated with levels of $15-\mathrm{F}_{2 \mathrm{t}}-\mathrm{IsoP}$ and MDA. These results agree with reports of our previous studies, coming from professional exposures monitoring and toxicology research. Bellisario et al. (2016), particularly, demonstrated a direct role of air-FA exposure on the alteration of the oxidative status, with higher levels of urinary $15-\mathrm{F}_{2 \mathrm{t}}-\mathrm{IsoP}$ and MDA in nurses employing FA, although MDA levels were found to be significantly higher only in nurses exposed to liquid FA, in particular, higher FA concentrations [7].

The high MDA levels in formalin-employers are noteworthy, since the interaction between this molecule and nucleic acid bases can lead to several adducts, including the 3(2-deoxy- $\beta$-D-erythro-pentafuranosyl)-pyrimido-[1,2- $\alpha$ ]-purin-10(3H)-onedG $\left(\mathrm{M}_{1} \mathrm{dG}\right)$ [63]. Specifically, in a study on pathologists' exposure to FA, the $\mathrm{M}_{1} \mathrm{dG}$ concentration was found to be significantly higher in workers than in the control group, with a dose-dependent relationship associated with exposures exceeding $66 \mu \mathrm{g} / \mathrm{m}^{3}$ [63]. In our study, the median FA concentration measured in the formalin-employers group was $57.3 \mu \mathrm{g} / \mathrm{m}^{3}$. Therefore, we can suppose that our sample, or at least a some of the volunteers enrolled, might be at risk of $\mathrm{M}_{1} \mathrm{dG}$ adducts formation.

Concerning the correlations between OS biomarkers, we also found a significant, positive correlation between MDA and $15-\mathrm{F}_{2 \mathrm{t}}-\mathrm{IsoP}$, about which contrasting reports have been previously published $[64,65]$.

The specific role of FA in triggering airway inflammation remains still unclear [26]. In a study on workers employed in the production and the utilisation of FA-melamine resins, Seow et al. (2015) highlighted a potential association between FA and immunosuppression, suggesting that high exposures may result in subtle immunological alterations [24]. We found a significant difference in TNF- $\alpha$ level, with the higher concentration in the formalinemployers group. This finding is remarkable, since TNF- $\alpha$ is able to trigger the transcription of the nuclear factor kappa B, involved, in turn, in both inflammatory and OS processes [61]. Moreover, these results are in line with the results provided by Oztan et al. (2020), reporting an increase in TNF- $\alpha$ and IL- 6 serum levels in workers employed in a fibre manufacturing company exposed to FA [60]. The significant positive correlation we found between TNF- $\alpha$ and MDA levels, might be considered as a possible link between the alteration in both inflammatory and oxidative status, even though contrasting reports can be found [66-68]. Our results, thus, could be further evidence of the role of FA in the immune profile alteration.

In this context, the investigation of genetic susceptibilities, and more specifically, the analysis of genetic polymorphisms that may be involved in modulating the individual susceptibility to occupational disease is of utmost importance [43]. Indeed, the results from previous studies and the present study could enable identification of worker subgroups susceptible to specific workplace exposures, and to provide useful inputs to update the current exposure limits [43].

In a recent review, Nielsen et al. (2017) reported that polymorphisms seem not to have any influence on modulating the genotoxic effect due to FA exposure [14]. Despite these premises, in our study we found lower MDA levels in GSTT1 Null subjects, both in the formalin-employers and non-employers, in formalin-employers GSTM1 Null and in those carrying at least one mutate allele for the CYP1A1 exon $7(A>G)$ gene.

GSTs are part of a family of phase II metabolising enzymes with a wide variety of biological roles, including cell protection against OS and toxic molecules. These enzymes are able to conjugate GSH to hydrophobic and electrophilic molecules, including carcinogens, drugs, and products of oxidative metabolism, making them less toxic and suitable to further modification and/or elimination [69]. The FA oxidation process requires GSH. Indeed, FA binds quickly and reversibly with GSH right after entering in the body, forming S-hydroxymethylglutathione, which is subsequently oxidised by cytosolic GSH-dependent FA-dehydrogenase. In an alternative pathway, free FA is first oxidised to formate, and then further to carbon dioxide [58]. In vitro studies confirmed that GSH depletion is one of the consequences of FA exposures: FA-induced cytotoxicity was proved to be influenced 
by intracellular GSH level [70], and, in neurons, FA exposure was found to induce GSH release, with an increase of the GSx amount in the extracellular medium [71]. The null genotype is characterised by a deletion of GSTM1 and GSTT1 genes, leading to the absence of the enzymes. The homozygous deletions are, thus, involved in a reduced elimination of carcinogens, and the carrier subjects are more susceptible to oxidative injuries [72]. Some studies have reported the association between deletion of the GSTT1 and GSTM1 genes and an increase in lipid peroxidation biomarkers, such as MDA [66,72]. Contrasting results are, instead, reported concerning the association between these two gene polymorphisms and genomic damage in FA exposed workers: some studies found no association [3,73] while Santovito et al. (2017b), in a pathologist sample, found significantly higher frequency of sister chromatid exchanges (SCEs) and chromosomal aberrations (CAs) in GSTT1 Null subjects. Thus, we can suppose that the lower reduction of MDA levels in GSTT1+ formalinemployers than in non-employers could be ascribed to FA's pro-oxidant role, overcoming the enzyme antioxidant activity. The lower MDA concentration found in subjects with at least a mutated allele for the CYP1A1 was in contrast with results reported in the literature, where the lower MDA levels were found in wt subjects $[67,68]$. The main limitation of this study is the cross-sectional design, which prevents the possibility of causal inferences. Longitudinal studies should be performed, in order to clarify causes of oxidative and inflammatory status alteration.

The strengths, on the other hand, consist in the quantification of personal exposure of workers enrolled in the study and in the measurement of many different biomarkers representing the different pathways that could be altered following the FA exposure. In addition, having also considered the genetic differences that could have an impact in the responsiveness to harmful exposure allowed us to highlight the importance of considering individual susceptibility in occupational settings.

\section{Conclusions}

This study confirms once more the role of FA exposure in the alteration of both oxidative and inflammatory profiles, highlighting how daily occupational exposure, even at low levels and in compliance with current legislation, can result in measurable biological outcomes. Moreover, this research highlights once more the importance of considering individual susceptibility biomarkers in the characterisation of biological outcomes following occupational exposures. These results, therefore, stress the relevance of preventive measures intended to reduce the FA exposure in workers who must use FA-based compounds during their work, e.g., vacuum systems for pathologists and nurses employed in operating theatres. In this scenario, in terms of public health and preventive strategies, gathering information on the different factors able to influence the biological outcome onset is of utmost importance in order to allow the definition of exposure limits for the safety of workers.

Author Contributions: Conceptualization, R.B., A.S. and V.B.; methodology, V.B., A.S. and F.G.; software, V.B. and G.S.; validation, G.S. and V.B.; formal analysis, F.G. and V.B., investigation, V.B., F.G., M.P. and A.S.; resources, R.B.; data curation, V.B., F.G. and G.S.; writing-original draft preparation, F.G.; writing-review and editing, F.G., M.P. and G.S.; visualization, F.G. and M.P.; supervision, R.B. and A.S.; project administration, R.B. and A.S.; funding acquisition, R.B. All authors have read and agreed to the published version of the manuscript.

Funding: This research was funded by the Office of Piedmont of the Italian Institute for Insurance against Accidents at Work (INAIL) by a grant to R.B. for the years 2013-2015.

Institutional Review Board Statement: The study was conducted according to the guidelines of the Declaration of Helsinki and approved by the Ethics Committee of Azienda ospedaliera Città della Salute e della Scienza of Torino (protocol code 0071900, 25 June 2013 and protocol code 0094007, 9 May 2013).

Informed Consent Statement: Informed consent was obtained from all subjects involved in the study. 
Data Availability Statement: The data presented in this study are available on request from the corresponding author. The data are not publicly available due to privacy restrictions.

Conflicts of Interest: The authors declare no conflict of interest.

\section{References}

1. Santovito, A.; Cervella, P.; Chiarizio, M.; Meschiati, G.; Delsoglio, M.; Manitta, E.; Picco, G.; Delpero, M. Relationships between cytokine (IL-6 and TGF- $\beta_{1}$ ) gene polymorphisms and chromosomal damage in hospital workers. J. Immunotoxicol. 2016, 13, 314-323. [CrossRef]

2. da Silva, M.A.; Giuntini, P.B.; Meneguin, S.H. A percepção dos profissionais da saúde frente à exposição a riscos químicos. Rev. Bras. Enferm. 1997, 50, 591-598. [CrossRef]

3. Santovito, A.; Schilirò, T.; Castellano, S.; Cervella, P.; Bigatti, M.P.; Gilli, G.; Bono, R.; DelPero, M. Combined analysis of chromosomal aberrations and glutathione S-transferase M1 and $\mathrm{T} 1$ polymorphisms in pathologists occupationally exposed to formaldehyde. Arch. Toxicol. 2011, 85, 1295-1302. [CrossRef]

4. Santovito, A.; Cervella, P.; Delpero, M. Increased frequency of chromosomal aberrations and sister chromatid exchanges in peripheral lymphocytes of radiology technicians chronically exposed to low levels of ionizing radiations. Environ. Toxicol. Pharmacol. 2014, 37, 396-403. [CrossRef] [PubMed]

5. Ioannou, S.; Andrianou, X.D.; Charisiadis, P.; Makris, K.C. Biomarkers of end of shift exposure to disinfection byproducts in nurses. J. Environ. Sci. 2017, 58, 217-223. [CrossRef] [PubMed]

6. Santovito, A.; Delsoglio, M.; Manitta, E.; Picco, G.; Meschiati, G.; Chiarizio, M.; Gendusa, C.; Cervella, P. Association of GSTT1 null, XPD 751 CC and XPC 939 CC genotypes with increased levels of genomic damage among hospital pathologists. Biomarkers 2017, 22, 557-565. [CrossRef] [PubMed]

7. Bellisario, V.; Mengozzi, G.; Grignani, E.; Bugiani, M.; Sapino, A.; Bussolati, G.; Bono, R. Towards a formalin-free hospital. Levels of 15-F2t-isoprostane and malondialdehyde to monitor exposure to formaldehyde in nurses from operating theatres. Toxicol. Res. (Camb.) 2016, 5, 1122-1129. [CrossRef]

8. Ghelli, F.; Cocchi, E.; Buglisi, M.; Squillacioti, G.; Bellisario, V.; Bono, R.; Santovito, A. The role of phase I, phase II, and DNA-repair gene polymorphisms in the damage induced by formaldehyde in pathologists. Sci. Rep. 2021, 11, 10507. [CrossRef]

9. Rumchev, K.B.; Spickett, J.T.; Bulsara, M.K.; Phillips, M.R.; Stick, S.M. Domestic exposure to formaldehyde significantly increases the risk of asthma in young children. Eur. Respir. J. 2002, 20, 403-408. [CrossRef] [PubMed]

10. Yang, X.; Zhang, Y.P.; Chen, D.; Chen, W.G.; Wang, R. Eye irritation caused by formaldehyde as an indoor air pollution-A controlled human exposure experiment. Biomed. Environ. Sci. 2001, 14, 229-236. [PubMed]

11. Hauptmann, M.; Lubin, J.H.; Stewart, P.A.; Hayes, R.B.; Blair, A. Mortality from Solid Cancers among Workers in Formaldehyde Industries. Am. J. Epidemiol. 2004, 159, 1117-1130. [CrossRef]

12. Beane Freeman, L.E.; Blair, A.; Lubin, J.H.; Stewart, P.A.; Hayes, R.B.; Hoover, R.N.; Hauptmann, M. Mortality from solid tumors among workers in formaldehyde industries: An update of the NCI cohort. Am. J. Ind. Med. 2013, 56, 1015-1026. [CrossRef]

13. Allegra, A.; Spatari, G.; Mattioli, S.; Curti, S.; Innao, V.; Ettari, R.; Allegra, A.G.; Giorgianni, C.; Gangemi, S.; Musolino, C. Formaldehyde exposure and acute myeloid leukemia: A review of the literature. Medicina 2019, 55, 638. [CrossRef]

14. Nielsen, G.D.; Larsen, S.T.; Wolkoff, P. Re-evaluation of the WHO (2010) formaldehyde indoor air quality guideline for cancer risk assessment. Arch. Toxicol. 2017, 91, 35-61. [CrossRef]

15. IARC Working Group on the Evaluation of Carcinogenic Risks to Humans; World Health Organization; International Agency for Research on Cancer. Formaldehyde, 2-Butoxyethanol and 1-tert-Butoxypropan-2-ol; International Agency for Research on Cancer: Lyon, France, 2006; ISBN 9283212886.

16. Shaham, J.; Gurvich, R.; Kaufman, Z. Sister chromatid exchange in pathology staff occupationally exposed to formaldehyde. Mutat. Res. Genet. Toxicol. Environ. Mutagen. 2002, 514, 115-123. [CrossRef]

17. Motta, O.; Charlier, B.; De Caro, F.; Coglianese, A.; De Rosa, F.; Moccia, G.; Pironti, C.; Capunzo, M.; Borrelli, A.; Filippelli, A.; et al. Environmental and biological monitoring of formaldehyde inside a hospital setting: A combined approach to manage chemical risk in workplaces. J. Public Health Res. 2021, 10, 2012. [CrossRef]

18. Zhang, L.; Beane Freeman, L.E.; Nakamura, J.; Hecht, S.S.; Vandenberg, J.J.; Smith, M.T.; Sonawane, B.R. Formaldehyde and leukemia: Epidemiology, potential mechanisms, and implications for risk assessment. Environ. Mol. Mutagen. 2010, 51, 181-191. [CrossRef]

19. Chiarella, P.; Tranfo, G.; Pigini, D.; Carbonari, D. Is it possible to use biomonitoring for the quantitative assessment of formaldehyde occupational exposure? Biomark. Med. 2016, 10, 1287-1303. [CrossRef] [PubMed]

20. Dugheri, S.; Bonari, A.; Pompilio, I.; Colpo, M.; Mucci, N.; Arcangeli, G. An Integrated Air Monitoring Approach for Assessment of Formaldehyde in the Workplace. Saf. Health Work 2018, 9, 479-485. [CrossRef] [PubMed]

21. Dugheri, S.; Massi, D.; Mucci, N.; Berti, N.; Cappelli, G.; Arcangeli, G. Formalin safety in anatomic pathology workflow and integrated air monitoring systems for the formaldehyde occupational exposure assessment. Int. J. Occup. Med. Environ. Health 2020, 34, 1-20. [CrossRef]

22. Fustinoni, S.; Campo, L.; Spinazzè, A.; Cribiù, F.M.; Chiappa, L.; Sapino, A.; Mercadante, R.; Olgiati, L.; Boniardi, L.; Cavallo, D.M.; et al. Exposure and Management of the Health Risk for the Use of Formaldehyde and Xylene in a Large Pathology Laboratory. Ann. Work Expo. Health 2021, 1-14. [CrossRef] 
23. D'Ettorre, G.; Criscuolo, M.; Mazzotta, M. Managing Formaldehyde indoor pollution in anatomy pathology departments. Work 2017, 56, 397-402. [CrossRef]

24. Jie Seow, W.; Zhang, L.; Vermeulen, R.; Tang, X.; Hu, W.; Bassig, B.A.; Ji, Z.; Shiels, M.S.; Kemp, T.J.; Shen, M.; et al. Circulating immune/inflammation markers in Chinese workers occupationally exposed to formaldehyde. Carcinogenesis 2015, 36, 852-857. [CrossRef] [PubMed]

25. Lima, L.F.; Murta, G.L.; Bandeira, A.C.B.; Nardeli, C.R.; Lima, W.G.; Bezerra, F.S. Short-term exposure to formaldehyde promotes oxidative damage and inflammation in the trachea and diaphragm muscle of adult rats. Ann. Anat. 2015, 202, 45-51. [CrossRef] [PubMed]

26. Li, L.; Hua, L.; He, Y.; Bao, Y. Differential effects of formaldehyde exposure on airway inflammation and bronchial hyperresponsiveness in BALB/c and C57BL/6 mice. PLOS ONE 2017, 12, e0179231. [CrossRef] [PubMed]

27. Czerska, M.; Mikołajewska, K.; Zieliński, M.; Gromadzińska, J.; Wasowicz, W. Today's oxidative stress markers. Med. Pr. 2015, 66, 393-405. [CrossRef]

28. Li, Y.R.; Trush, M. Defining ROS in Biology and Medicine. React. Oxyg. Species 2016, 1, 9. [CrossRef] [PubMed]

29. Khoubnasabjafari, M.; Ansarin, K.; Jouyban, A. Reliability of malondialdehyde as a biomarker of oxidative stress in psychological disorders. BioImpacts 2015, 5, 123-127. [CrossRef]

30. Niki, E. Biomarkers of lipid peroxidation in clinical material. Biochim. Biophys. Acta Gen. Subj. 2014, 1840, 809-817. [CrossRef]

31. Milne, G.L.; Dai, Q.; Roberts, L.J. The isoprostanes-25 years later. Biochim. Biophys. Acta 2015, 1851, 433-445. [CrossRef]

32. Tan, B.L.; Norhaizan, M.E.; Liew, W.P.P.; Rahman, H.S. Antioxidant and oxidative stress: A mutual interplay in age-related diseases. Front. Pharmacol. 2018, 9, 1162. [CrossRef]

33. Oeltzschner, G.; Butz, M.; Wickrath, F.; Wittsack, H.J.; Schnitzler, A. Covert hepatic encephalopathy: Elevated total glutathione and absence of brain water content changes. Metab. Brain Dis. 2016, 31, 517-527. [CrossRef] [PubMed]

34. Haffner, M.J.; Oakes, P.; Demerdash, A.; Yammine, K.C.; Watanabe, K.; Loukas, M.; Tubbs, R.S. Formaldehyde exposure and its effects during pregnancy: Recommendations for laboratory attendance based on available data. Clin. Anat. 2015, 28, 972-979. [CrossRef] [PubMed]

35. Zmorzyński, S.; Świderska-Kołacz, G.; Koczkodaj, D.; Filip, A.A. Significance of Polymorphisms and Expression of EnzymeEncoding Genes Related to Glutathione in Hematopoietic Cancers and Solid Tumors. BioMed Res. Int. 2015, 2015, 853573. [CrossRef] [PubMed]

36. Pisoschi, A.M.; Pop, A. The role of antioxidants in the chemistry of oxidative stress: A review. Eur. J. Med. Chem. 2015, 97, 55-74. [CrossRef]

37. Moreno-Macias, H.; Romieu, I. Effects of antioxidant supplements and nutrients on patients with asthma and allergies. J. Allergy Clin. Immunol. 2014, 133, 1237-1244. [CrossRef] [PubMed]

38. Jia, X.; Jia, Q.; Zhang, Z.; Gao, W.; Zhang, X.; Niu, Y.; Meng, T.; Feng, B.; Duan, H.; Ye, M.; et al. Effects of Formaldehyde on Lymphocyte Subsets and Cytokines in the Peripheral Blood of Exposed Workers. PLoS ONE 2014, 9, e104069. [CrossRef]

39. Aydın, S.; Canpınar, H.; Ündeğer, Ü.; Güç, D.; Çolakoğlu, M.; Kars, A.; Başaran, N. Assessment of immunotoxicity and genotoxicity in workers exposed to low concentrations of formaldehyde. Arch. Toxicol. 2013, 87, 145-153. [CrossRef]

40. Kastner, P.E.; Casset, A.; Pons, F. Formaldehyde interferes with airway epithelium integrity and functions in a dose- and time-dependent manner. Toxicol. Lett. 2011, 200, 109-116. [CrossRef]

41. Balharry, D.; Sexton, K.; BéruBé, K.A. An in vitro approach to assess the toxicity of inhaled tobacco smoke components: Nicotine, cadmium, formaldehyde and urethane. Toxicology 2008, 244, 66-76. [CrossRef]

42. Wang, F.; Li, C.; Liu, W.; Jin, Y. Effect of exposure to volatile organic compounds (VOCs) on airway inflammatory response in mice. J. Toxicol. Sci. 2012, 37, 739-748. [CrossRef]

43. Christiani, D.C.; Mehta, A.J.; Yu, C.L. Genetic susceptibility to occupational exposures. Occup. Environ. Med. 2008, 65, 430-436. [CrossRef]

44. Parveen, F.; Faridi, R.M.; Das, V.; Tripathi, G.; Agrawal, S. Genetic association of phase I and phase II detoxification genes with recurrent miscarriages among North Indian women. Mol. Hum. Reprod. 2010, 16, 207-214. [CrossRef]

45. Yang, X.-L.; Xie, S.; Jiang, Y.-Y.; Shi, C.; Cai, Z.-G.; Chen, S.-X. Association between CYP1A1 Ile462Val Polymorphism and Oral Squamous Cell Carcinoma Susceptibility: Evidence from 13 Investigations. J. Cancer 2015, 6, 302-309. [CrossRef]

46. Hollman, A.L.; Tchounwou, P.B.; Huang, H.-C. The Association between Gene-Environment Interactions and Diseases Involving the Human GST Superfamily with SNP Variants. Int. J. Environ. Res. Public Health 2020, 13, 379. [CrossRef] [PubMed]

47. Squillacioti, G.; Bellisario, V.; Grosso, A.; Ghelli, F.; Piccioni, P.; Grignani, E.; Corsico, A.; Bono, R. Formaldehyde, Oxidative Stress, and FeNO in Traffic Police Officers Working in Two Cities of Northern Italy. Int. J. Environ. Res. Public Health 2020, $17,1655$. [CrossRef]

48. Ghelli, F.; Bellisario, V.; Squillacioti, G.; Grignani, E.; Garzaro, G.; Buglisi, M.; Bergamaschi, E.; Bono, R. Oxidative stress induction in woodworkers occupationally exposed to wood dust and formaldehyde. J. Occup. Med. Toxicol. 2021, 16, 4. [CrossRef]

49. Bartels, H.; Cikes, M. Über chromogene der kreatininbestimmung nach Jaffé. Clin. Chim. Acta 1969, 26, 1-10. [CrossRef]

50. De Moraes Martins, C.J.; Genelhu, V.; Pimentel, M.M.G.; Celoria, B.M.J.; Mangia, R.F.; Aveta, T.; Silvestri, C.; Di Marzo, V.; Francischetti, E.A. Circulating endocannabinoids and the polymorphism 385C >A in fatty acid amide hydrolase (FAAH) gene may identify the obesity phenotype related to cardiometabolic risk: A study conducted in a Brazilian population of complex interethnic admixture. PLoS ONE 2015, 10, e0142728. [CrossRef] 
51. Chen, S.; Xue, K.; Xu, L.; Ma, G.; Wu, J. Polymorphisms of the CYP1A1 and GSTM1 genes in relation to individual susceptibility to lung carcinoma in Chinese population. Mutat. Res. Mutat. Res. Genom. 2001, 458, 41-47. [CrossRef]

52. Pemble, S.; Schroeder, K.R.; Spencer, S.R.; Meyer, D.J.; Hallier, E.; Bolt, H.M.; Ketterer, B.; Taylor, J.B. Human glutathione S-transferase Theta (GSTT1): cDNA cloning and the characterization of a genetic polymorphism. Biochem. J. 1994, 300, $271-276$. [CrossRef]

53. Zhong, S.; Wyllie, A.H.; Barnes, D.; Wolf, C.R.; Spurr, N.K. Relationship between the gstm1 genetic polymorphism and susceptibility to bladder, breast and colon cancer. Carcinogenesis 1993, 14, 1821-1824. [CrossRef]

54. Perrey, C.; Turner, S.J.; Pravica, V.; Howell, W.M.; Hutchinson, I.V. ARMS-PCR methodologies to determine IL-10, TNF- $\alpha$, TNF- $\beta$ and TGF- $\beta 1$ gene polymorphisms. Transpl. Immunol. 1999, 7, 127-128. [CrossRef]

55. Zakharyan, R.; Petrek, M.; Arakelyan, A.; Mrazek, F.; Atshemyan, S.; Boyajyan, A. Interleukin-6 promoter polymorphism and plasma levels in patients with schizophrenia. Tissue Antigens 2012, 80, 136-142. [CrossRef] [PubMed]

56. Titford, M.E.; Horenstein, M.G. Histomorphologic Assessment of Formalin Substitute Fixatives for Diagnostic Surgical Pathology. Arch. Pathol. Lab. Med. 2005, 129, 502-506. [CrossRef] [PubMed]

57. Patil, S.; Rao, R.S.; Ganavi, B.S.; Majumdar, B. Natural sweeteners as fixatives in histopathology: A longitudinal study. J. Nat. Sci. Biol. Med. 2015, 6, 67-70. [CrossRef]

58. Ye, X.; Ji, Z.; Wei, C.; McHale, C.M.; Ding, S.; Thomas, R.; Yang, X.; Zhang, L. Inhaled formaldehyde induces DNA-protein crosslinks and oxidative stress in bone marrow and other distant organs of exposed mice. Environ. Mol. Mutagen. 2013, 54, 705-718. [CrossRef]

59. Li, X.; Zhang, F.; Zhou, H.; Hu, Y.; Guo, D.; Fang, X.; Chen, Y. Interplay of TNF- $\alpha$, soluble TNF receptors and oxidative stress in coronary chronic total occlusion of the oldest patients with coronary heart disease. Cytokine 2020, 125, 154836. [CrossRef]

60. Oztan, O.; Tutkun, L.; Turksoy, V.A.; Deniz, S.; Dip, A.; Iritas, S.B.; Eravci, D.B.; Alaguney, M.E. The relationship between impaired lung functions and cytokine levels in formaldehyde exposure. Arch. Environ. Occup. Health 2021, 76, 248-254. [CrossRef]

61. Reuter, S.; Gupta, S.C.; Chaturvedi, M.M.; Aggarwal, B.B. Oxidative stress, inflammation, and cancer: How are they linked? Free Radic. Biol. Med. 2010, 49, 1603-1616. [CrossRef] [PubMed]

62. Klaunig, J.E.; Wang, Z. Oxidative stress in carcinogenesis. Curr. Opin. Toxicol. 2018, 7, 116-121. [CrossRef]

63. Bono, R.; Romanazzi, V.; Munnia, A.; Piro, S.; Allione, A.; Ricceri, F.; Guarrera, S.; Pignata, C.; Matullo, G.; Wang, P.; et al. Malondialdehyde-Deoxyguanosine Adduct Formation in Workers of Pathology Wards: The Role of Air Formaldehyde Exposure. Chem. Res. Toxicol. 2010, 23, 1342-1348. [CrossRef]

64. Martinez-Moral, M.P.; Kannan, K. How stable is oxidative stress level? An observational study of intra- and inter-individual variability in urinary oxidative stress biomarkers of DNA, proteins, and lipids in healthy individuals. Environ. Int. 2019, 123, 382-389. [CrossRef] [PubMed]

65. Basu, S. The enigma of in vivo oxidative stress assessment: Isoprostanes as an emerging target. Scand. J. Food Nutr. 2007, 51, 48-61. [CrossRef]

66. Datta, S.K.; Kumar, V.; Pathak, R.; Tripathi, A.K.; Ahmed, R.S.; Kalra, O.P.; Banerjee, B.D. Association of glutathione $S$-transferase M1 and T1 gene polymorphism with oxidative stress in diabetic and nondiabetic chronic kidney disease. Ren. Fail. 2010, 32, 1189-1195. [CrossRef] [PubMed]

67. Hong, Y.C.; Lee, K.H.; Yi, C.H.; Ha, E.H.; Christiani, D.C. Genetic susceptibility of term pregnant women to oxidative damage. Toxicol. Lett. 2002, 129, 255-262. [CrossRef]

68. Vibhuti, A.; Arif, E.; Mishra, A.; Deepak, D.; Singh, B.; Rahman, I.; Mohammad, G.; Pasha, M.A.Q. CYP1A1, CYP1A2 and CYBA gene polymorphisms associated with oxidative stress in COPD. Clin. Chim. Acta 2010, 411, 474-480. [CrossRef] [PubMed]

69. Allocati, N.; Masulli, M.; Di Ilio, C.; Federici, L. Glutathione transferases: Substrates, inihibitors and pro-drugs in cancer and neurodegenerative diseases. Oncogenesis 2018, 7, 1-15. [CrossRef]

70. Ho, Y.-C.; Huang, F.-M.; Chang, Y.-C. Cytotoxicity of formaldehyde on human osteoblastic cells is related to intracellular glutathione levels. J. Biomed. Mater. Res. Part B Appl. Biomater. 2007, 83, 340-344. [CrossRef]

71. Tulpule, K.; Hohnholt, M.C.; Dringen, R. Formaldehyde metabolism and formaldehyde-induced stimulation of lactate production and glutathione export in cultured neurons. J. Neurochem. 2013, 125, 260-272. [CrossRef]

72. Kumar, V.; Yadav, C.S.; Datta, S.K.; Singh, S.; Ahmed, R.S.; Goel, S.; Gupta, S.; Mustafa, M.; Grover, R.K.; Banerjee, B.D. Association of GSTM1 and GSTT1 polymorphism with lipid peroxidation in benign prostate hyperplasia and prostate cancer: A pilot study. Dis. Mark. 2011, 30, 163-169. [CrossRef]

73. Costa, S.; Carvalho, S.; Costa, C.; Coelho, P.; Silva, S.; Santos, L.S.; Gaspar, J.F.; Porto, B.; Laffon, B.; Teixeira, J.P. Increased levels of chromosomal aberrations and DNA damage in a group of workers exposed to formaldehyde. Mutagenesis 2015, 30, 463-473. [CrossRef] [PubMed] 